\title{
Üstün Zekâlılar Öğretmenliği Adaylarının Gözlerinden Bilim İnsanları
}

\section{Sezen CAMCI ERDOĞAN*}

Öz: Çalışma, üstün zekâlılar öğretmenliği adaylarının bilim insanlarına yönelik sahip olduğu imajların incelenmesini amaçlamaktadır. Nitel araştırma modeli ile yürütülen çalışmaya, üstün zekâlılar öğretmenliği adaylarından oluşan 87 kişilik gönüllü bir grup katılmıştır. Veriler Chambers (1983) tarafından geliştirilen Bir Bilim İnfsanı Çiz Testi (The Draw A-Scientist Test) ve açık uçlu sorularla toplanmıştır. Öğrenci çizimleri bilim insanının özelliklerine (dış görünüş, cinsiyet vb.) ait farklı kriterler açısından değerlendirilmiştir. Araştırma sonuçları, daha önce yapılan çalışmalara paralel sonuçlar vermiş ve öğretmen adaylarının bilim insanı imajlarının standart olduğu, bilim insanlarının genellikle gözlüklü, laboratuvar önlüğü giymiş, iç ortamda deney tüpleri, beherler ile çalışan, kitap ve teknoloji ürünleri kullanan ve baskın olarak yalnız olarak çalışan erkekler olduğu ortaya çıkmıştır.

Anahtar Kelimeler: Bilim insanı, imaj, üstün zekâlılar öğretmenliği adayı

\section{Images of Scientists Through The Eyes of Pre-Service Teachers of Gifted Students}

Abstract: The purpose of this study is to investigate the images of scientists through the eyes of pre-service teachers of gifted students. The study involved 87 volunteer preservice teachers. Data gathered from Chamber (1983)'s Draw-a-Scientist Test (DAST) and open-ended questions. Students' drawings were evaluated based on some criterions

\footnotetext{
* Yrd. Doç. Dr. İstanbul Üniversitesi, Hasan Ali Yücel Eğitim Fakültesi, Özel Eğitim Bölümü/ E-mail: scamci@istanbul.edu.tr, orcid id: 0000-0002-5059-9168
} 
of scientist's characteristics (e.g., appearance, gender). The results are similar to prior studies and indicate that students' images about scientists are stereotypical; images are generally with glasses, laboratory coats, working with experiment tubes indoors; using books and dominantly alone males in laboratories.

Keywords: Scientist, image, pre-service teachers of gifted students

\section{Giriş}

Sputnik'in uzaya fırlatılması ile başlayan ülkeler arasındaki bilim ve teknolojideki ilerleme yarışında, "herkes için bilim” düşüncesi ile bilime herkesin ulaşabileceği ve herkesin bilim okuryazarı olabileceği üzerine vurgu yapılmıştır. Bu bağlamda toplumun özellikle de öğrencilerin, bilimi daha ulaşılabilir algılaması ve bilime yönelik olumlu tutumlara sahip olması ön plana çıkmıştır. Bilimi daha ulaşılabilir hale getirilmeye çalışılması ile bilime ve bilim insanlarına yönelik ilgi ve tutumlar önem kazanarak, araştırma konusu haline gelmiştir. Bireylerin ilk bilim deneyimlerinin temellerinin ilköğretimde atıldığı düşünüldüğünde, ilköğretim öğrencilerinin bilime ve bilim insanlarına yönelik sahip olduğu ilgi, tutum ve performansları üzerinde, öğretmenlerin sahip olduğu tutumların ve hazırladıkları öğrenme ortamının etkili olduğu ortaya koyulmuştur (Carnes 2009; Christidou 2011; She ve Fisher, 2002; Sönmez, 2007; Washton, 1971). Bununla birlikte bilim ve bilim insanlarına yönelik olumsuz tutum geliştiren öğrencilerin bilimsel konuları ilgi çekici olarak görmedikleri ve gelecekte bilimle ile ilgili bir ders ya da meslek seçmek istemedikleri ortaya konulmuştur (Hammrich, 1997; Milford ve Tippet, 2013; Rosenthal, 1993).

Üstün zekâlı öğrencilerin ise bilimsel konulara, içgüdüsel olarak var olan merak ve hayal güçlerini beslediği için doğuştan ilgileri vardır (SmutnyVon ve Fremd, 2004). Spesifik örneklerden edindikleri bilgileri, günlük hayatta yaşadıkları olaylara transfer 
etme noktasında bir iç görü ve anlayışa sahiptirler (Kopelman, Galasso ve Strom, 1977; Ngoi ve Vodracek, 2004). Bu bilgileri, etraflarını yakından gözlemleyerek (Karnes ve Riley, 2005), başkalarının kaçırdı̆̆ı problemleri fark edip, tanımlayarak (Meador, 2003) ve açık uçlu problem durumlarının araştırılmasından zevk alarak elde ederler. Bilimsel konulara yönelik motivasyon, ısrar, keşfetme becerisi ve doğal yeteneği barındıran bir tutkuları vardır. Bilimsel olayları araştırma noktasında oldukça ilgili olma, gözlem yapma ve soru sormaya eğilimli olma ve bilimin herhangi bir disiplinine yönelik derinlemesine ilgiye sahip olma (Cooper, Baum ve Neu, 2004, 2005; Taber, 2007) gibi özelliklere sahip bu öğrencilere eğitim verecek öğretmenlerin onların bu motivasyon, istek ve ilgilerini destekleyecek ve daha ileriye götürebilecek düzeyde olması gerekmektedir; çünkü ilköğretim öğretmenleri, bilime ve bilim insanlarına yönelik birincil kaynaklardandır ve öğrencileri üzerinde sahip oldukları etki yadsınamayacak düzeydedir (Matthews ve Davies, 1996; Christidou 2011; Moseley ve Norris, 1999).

Bilim insanlarına yönelik sahip olunan imajlar, Mead ve Metraux (1957)'un lise öğrencileri ile yaptıkları çalışmaya dayanmaktadır. $\mathrm{Bu}$ çalışmada, öğrencilerin zihinlerindeki bilim insanının yaşlı, gözlüklü, dağınık, beyaz önlük giyerek laboratuvarda çalışan (daha çok kimyasallar, bünzenler, cam şişeler vb ile) erkek olduğu ifade edilmiştir. Mead ve Metraux (1957)'un çalışmalarından ilham alan ve bu alanda birçok çalışmaya öncülük eden Chambers (1983) okul öncesinden beşinci sınıfa kadar süren 11 yıllık boylamsal çalışmasını DAST (Draw A Scientist Test-Bir Bilim İnsanı Çiz Testi)'^ uygulayarak 4807 öğrenci ile yürütmüştür. Yaptığı bu çalışma sonucunda DAST testinde standart bilim insanı göstergesi olarak değerlendirilebilecek yedi gösterge belirlemiştir. Bu yedi gösterge: 1. Laboratuvar Önlüğü, 2. Gözlük;, 3. Sakal, Bıyık, 4. Araştırma Sembolleri, . Bilgi Sembolleri, 6. Teknoloji Kullanımı, 7. Başlıklar, 
Konuşma Balonlarıdır. Aynı çalışmada öğrencilerin sınıf düzeyleri arttıkça, çizimlerindeki bu standart yedi göstergenin de arttığı görülmüştür. Bununla birlikte yaş düzeyi arttıkça, öğrencilerin teknolojiyi ifade eden semboller (TV, mikroskop, uzay araçları vb.) çizdikleri gözlenmiştir. Chambers (1983)'ın yaptığı çalışmada kadın bilim insanlarını sadece kız öğrencilerin çizdiği ve genel olarak bilim insanlarının iç mekânda çalışırken çizildiği gözlenmiştir.

Chambers (1983)'ın çalışmasından sonra ilköğretim ve lise düzeyindeki öğrencilerle yapılan, farklı örneklemlerle de çalışan birçok araştırmacının sonuçlarından (hangi yaş, cinsiyet ya da kültür olursa olsun), bilim insanı imajlarının gözlük takan, önlük giyen, deney tüpleri ve beherlerle laboratuvarda yalnız çalışan erkek gibi ortak özellikler gösterdiği ortaya koyulmuştur (Akcay, 2011; Buldu, 2006; Camc1, 2008; Camc1-Erdoğan, 2013a, 2013b; Chambers, 1983; Flick, 1990; Fort ve Varney, 1989; Fung, 2002; Gonsoulin 2001; Kaya, Doğan ve Öcal, 2008; Kemaneci, 2012; Mead ve Metraux, 1957; Schibeci, 2006; Song ve Kim, 1999; Symington ve Spurling, 1990; Türkmen, 2008; Yontar-Toğrol, 2000).

Öğrencilerin bilime ve bilim insanına yönelik sahip olduğu imajlar üzerinde etkisi olduğu ifade edilen öğretmenlerin ya da öğretmen adaylarının sahip olduğu bilim insanı imajlarına yönelik yapılan çalışmalara bakıldığında, bu çalışmaların az sayıda olduğu göze çarpmaktadır. Konu ile ilgili ulaşılabilen çalışmalarda daha çok sınıf öğretmenliği ve okul öncesi öğretmenliği adayları ile çalışıldığı gözlemlenmiştir. Bu çalışmalar sonucunda ise öğretmen adaylarının da diğer yaş düzeylerinde yapılan çalışmalara paralel olarak laboratuvar ortamında, tehlikeli kimyasallar ile deney yapan, gözlüklü, laboratuvar önlüklü orta yaş yalnız erkek bilim insanları çizdikleri 
gözlemlenmiştir (Çermik, 2013; Moseley ve Norris, 1999; Reap, Cavallo ve McWhirter, 1994; Şenel ve Aslan, 2014; Ünver, 2010; Ürey, Karaçöp, Göksu ve Çolak, 2017).

Günümüzde bilimsel okuryazarlık terimi ile birlikte toplumun her kesiminin bilimsel bilgiyi anlamlandırması hedeflenmektedir. Bilimsel bilginin üretilmesi için bilim insanlarının yetiştirilip, yaratıcı çalışmaların devamlılığının sağlanması önemlidir. Bilim ve bilim yapmanın bu denli önemli olduğu günümüzde üstün zekâlı öğrenciler sahip oldukları ileri üst düzey düşünme becerileri ve yaratıcılıkları noktasında bilim yapmaya yönlendirmeye çalıştığımız ve bu alanlarda uzmanlaşmaları için çaba sarf ettiğimiz bireylerdir. Van Tassel-Baska ve Kulieke (1987) üstün zekâlı öğrencilerin bilimsel merak ve ihtiyaçlarının öncelikle bilimi ve bilim insanlarını doğru algılamaları ile gerçekleştirilebileceğini ifade etmektedir. $\mathrm{Bu}$ bağlamda doğru algının oluşturulmasında ve pekiştirilmesinde; öğrencilerin farklı rol modellerle karşılaştırılmasında en büyük pay öğretmenlere düşmektedir. Bu yüzden öğretmenlerin bilim ve bilim insanlarına yönelik sahip olduğu bilgi, tutum ve bakış açısı da önemlidir. Fakat özellikle ilköğretim düzeyinde bilim ve bilim insanları ile ilgili bu öğrencilere doğru ilgi ve imajları kazanmalarında rehberlik ve kaynaklık edecek öğretmenlere ya da öğretmen adaylarına yönelik çalışmalara, yapılan araştırmalar sonucunda ulaşılamamıştır.

Çalışmanın Amacı: Çalışmanın amacı, üstün zekâlılar öğretmenliği adaylarının sahip olduğu bilim insanı imajlarının incelenmesidir. Üstün zekâlı öğrencilerin bilime ve bilim insanlarına olan ilgisinin oluşturulmasında ya da zaten var olan ilgisinin artırılmasında, bu öğrencilere ileride rehberlik edecek öğretmen adaylarının sahip olduğu bilim insanı algısının belirlenmesi gerekmektedir. Bu çalışma ile ortaya çıkan veriler 1şığında ilköğretim, ortaöğretim ve üniversite ve özelinde eğitim fakültesi 
öğretmen yetiştirme programlarında, bilime ve bilim insanına yönelik algıların farklılaştırılması ve standartlaştırılmaması için farklı uygulamaların ve çalışmaların yapılması noktasına katkı sağlaması amaçlanmaktadır.

\section{Yöntem}

Çalışmanın Deseni: Doküman analizi ve açık uçlu soru gibi nitel veri toplama yöntemlerinin kullanıldığg üstün zekâlılar öğretmenliği adaylarının bilim insanına yönelik imajlarının cinsiyet ve sınıf düzeyi değişkenlerine göre farklılık gösterip göstermediğini ortaya koyan bu çalışma, nitel araştırma yöntemlerinden durum çalışması olarak ortaya koyulmuştur.

Katılımcılar: Çalışmaya, 2014-2015 eğitim öğretim yılında Türkiye’nin büyük şehirlerinden birinde yer alan bir üniversitenin Üstün Zekâl1lar Öğretmenliği programında öğrenim gören ve araştırmaya gönüllü olarak katılmak isteyen birinci, üçüncü ve dördüncü sınıf öğrencileri katılmıştır. İkinci sınıf öğrencileri daha önce bilim ve bilim insanlarına yönelik algımız konusu hakkında bir seminer eğitimi aldıkları için, çalışmaya dâhil edilmemişlerdir. Katılımcı sayılarına ait bilgiler Tablo 1'de verilmiştir.

Tablo 1. Katılımcıların Sinıflara Göre Dă̆ılımı

\begin{tabular}{|c|c|c|c|}
\hline Cinsiyet & 1. Sinif & 3. Sinif & 4. $\quad \sin 1 f$ \\
\hline K1z & 26 & 14 & 12 \\
\hline Erkek & 8 & 7 & 20 \\
\hline Toplam & 34 & 21 & 32 \\
\hline
\end{tabular}

Veri Toplama Aracı: Çalışmada kullanılan veri toplama araçları üç parçadan oluşmakla birlikte, hepsi ard arda ve toplu bir şekilde uygulanmıştır. İlk kısımda öğrencilerin yaş, cinsiyet, sınıf vb. bilgilerini soran kişisel bilgi formu kullanılmıştır. İkinci kısımda ise Bir Bilim İnsanı Çiz (Draw A Scientist Test-DAST; Chambers, 1987) testi kullanılmıştır. Bu kısımda öğrencilere şu yönerge verilir: "Lütfen gözlerinizi kapatın ve bir bilim insanını çalışırken hayal edin. Gözlerinizi açın ve hayal ettiğiniz 
bilim insanını çizin. Çizdiğiniz bilim insanının cinsiyetini ve yaşını işaretleyin.”. İkinci kısım tamamlandıktan sonra, üçüncü kısıma geçilmiştir. Üçüncü kısımda katılımcıların bilim insanlarına yönelik sahip olduğu imajların kaynaklarını ortaya koymayı ve bu imajlara yönelik iki açık uçlu soruya cevap aramayı amaçlamıştır. Bu sorular : “Favori bilim insanınız kimdir?” ve “Etrafınızda bilim insanı olarak gördüğünüz biri/birileri var mı?” şeklindedir.

\section{Verilerin Çözümlenmesi:}

Verilerin çözümlenmesi kısmında, öğretmen adaylarının çizimleri incelenerek, boş bırakılan iki veri toplama formu araştırma kapsamından çıkarılmıştır. Elde edilen formlara numaralar verilerek kontrol listesi uyarınca kodlamalar yapılmıştır. DAST sonucunda çizilen bilim insanı imajlarının değerlendirilmesinde aşağıdaki kontrol listesi kullanılır. Kontrol listesinde görülen özellikler çizimde var ise 1, yok ise 0 olarak kodlanmıştır. Kodlamalar üstün zekalılar öğretmenliği eğitimi alanında çalışan iki uzman tarafından yapılmıştır. Elde edilen kodların güvenirliği Milles ve Haberman (2002) güvenirlik formülü [Görüş birliği / (Görüş birliği + Görüş ayrılığı)] kullanılmış ve her bir kriter için güvenirlik katsayısı hesaplanmıştır. Kodlamada yer alan kriterler ve sahip oldukları güvenirlik katsayıları aşağıdaki gibidir:

Tablo 2. DAST Çizim Kriterleri ve Kodların Güvenirlik Katsayıları Kontrol Kriterleri

1. Bilim insanının dış görünüşü (gözlük, Kodların Güvenirlik Katsayısı laboratuvar önlüğü, gözlük, dağınık görünüm vb.)

2. Araç Gereçler

a. Araştırma sembolleri (tüp, beher vb.) .88

b. Bilgi sembolleri (kitaplar, raflar) $\quad .83$

\begin{tabular}{ll} 
c. Teknoloji sembolleri (TV, bilgisayar etc.) & .83 \\
\hline
\end{tabular}

d. Çizim ile ilgili başlıklar, yazılar (formül, $\quad .75$

"buldum",

3. Bilim insanının çalışma yeri:

a. İç mekan

.92

b. Diș mekan

.91 
Bilim insanının cinsiyeti ve yaşı öğretmen adaylarının seçtikleri seçenek doğrultusunda kodlanırken, açık uçlu iki soruda ise öğrencilerin cevaplarının listesi oluşturulmuş daha sonra bu cevaplar kategorik olarak kodlanmış ve cevaplara dair örneklemeler yapılmıştır. DAST testinden ve açık uçlu sorulara verilen cevaplardan elde edilen kategorik veriler, yüzdeleri (\%) ve frekansları hesaplanarak sunulmuştur.

\section{Bulgular}

\section{Dış Görünüş Özellikleri ve Araştırma, Bilgi ve Teknoloji (ABT) Sembolleri}

Üstün zekâlılar öğretmenliği adaylarının sahip olduğu bilim insanı imajları çizimlerinden yansıttıkları dış görünüş özellikleri açısından bulgulara Tablo 1'de yer verilmektedir.

Tablo 3. Dıș Görünüş Özellikleri ve ABT Sembolleri

\begin{tabular}{|c|c|c|c|c|c|c|}
\hline \multirow[t]{2}{*}{$(\mathrm{N}=87)$} & \multicolumn{2}{|l|}{ Cinsiyet } & \multirow[b]{2}{*}{$\begin{array}{l}\text { Toplam } \\
\text { f(\%) }\end{array}$} & \multicolumn{3}{|l|}{ Sinıf } \\
\hline & Kız f(\%) & Erkek f(\%) & & $\begin{array}{l}\text { 1.Sinıf } \\
\text { f(\%) }\end{array}$ & 3.Sinıf f(\%) & $\begin{array}{l}\text { 4.Sinıf } \\
\text { f(\%) }\end{array}$ \\
\hline Lab. Önl. & $15(29)$ & $3(9)$ & $18(21)$ & $6(18)$ & $6(29)$ & $6(19)$ \\
\hline Gözlük & $23(44)$ & $11(31)$ & $34(39)$ & $12(35)$ & $10(48)$ & $12(38)$ \\
\hline Yüz. K1l. & $8(15)$ & $5(14)$ & $13(15)$ & $4(12)$ & $5(24)$ & $4(13)$ \\
\hline Dağınık & $11(21)$ & $9(26)$ & $20(23)$ & $5(15)$ & $8(38)$ & $7(22)$ \\
\hline Araștırma & $28(54)$ & $12(34)$ & $40(46)$ & $22(65)$ & $8(38)$ & $10(31)$ \\
\hline Bilgi & $27(52)$ & $19(54)$ & $46(53)$ & 20(59) & $5(24)$ & $21(67)$ \\
\hline Teknoloji & $14(27)$ & $10(27)$ & $24(27)$ & $12(35)$ & $7(33)$ & $5(16)$ \\
\hline
\end{tabular}

Buna göre sınıf düzeyleri ve cinsiyet ayırt edilmeksizin bakıldığında, öğretmen adaylarının bilim insanını gözlüklü $(n=34, \% 39)$, laboratuvar önlüğü giyen $(n=20$, \%23), dağınık görünümlü $(n=20, \% 23)$ olarak hayal ettiği ortaya çıkmıştır. Sınıf düzeyleri açısından incelendiğinde ise, her sınıf düzeyinde öğrencilerin en çok gözlük takan ve dağınık görünümlü bilim insanları çizdikleri görülmüştür. Cinsiyet değişkeni açısından değerlendirildiğinde de hem kı $(n=23, \% 44)$ hem de erkek (n $=11, \% 31$ ) öğrencilerin en çok gözlüklü bilim insanı çizdikleri görülmüştür. 


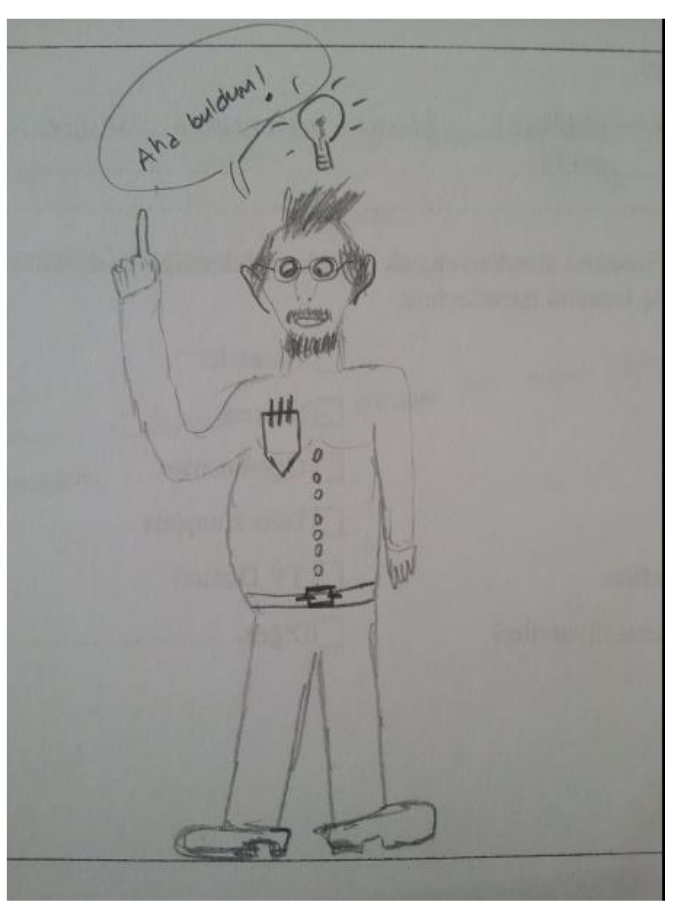

Şekil 1: Gözlüklü, laboratuvar önlüklü dağınık erkek bilim insanı; 3. sınıf kız

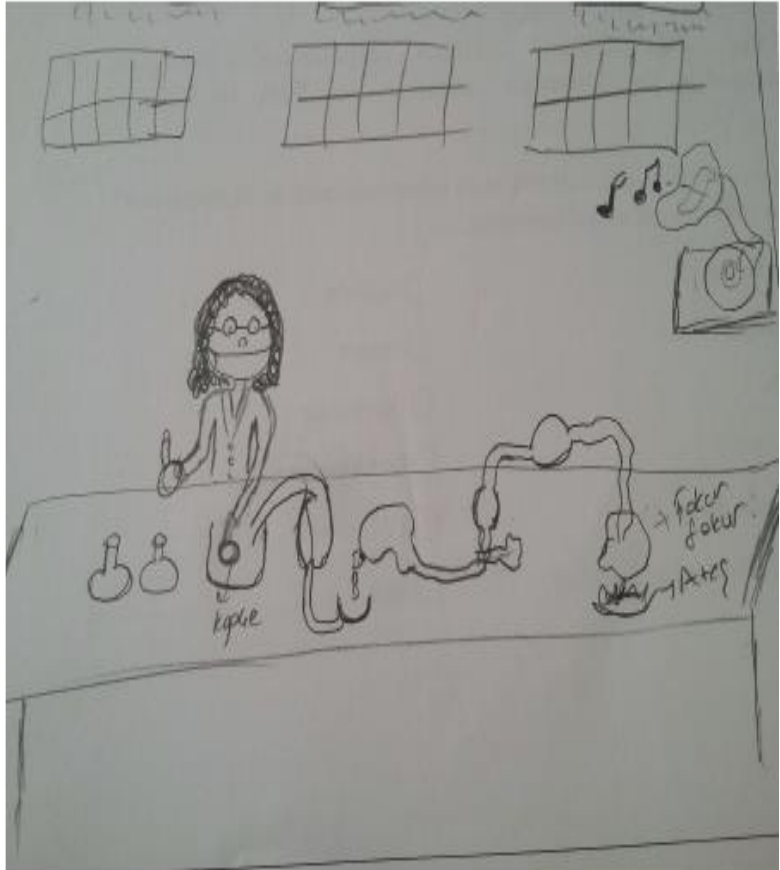

Şekil 2: Gözlüklü laboratuvar önlüklü kadın bilim insanı; 4. sınıf kız

Üstün zekâlılar öğretmenliği adaylarının çizimlerinde kullandığı ABT sembollerine yönelik bulgulara bakıldığında, sınıf düzeyi ya da cinsiyet gözetilmeksizin öğrencilerin büyük çoğunluğunun bilim insanını kitaplardan araştırmalar yapan, notlar tutan $(n=46, \% 53)$ bilim insanı olarak resmettikleri görülmüştür. Sınıf düzeyleri açısından incelendiğinde, 1. sınıf öğrencilerinin hem deney tüpü, beher, kimyasal vb. gibi deney aparatları düzeneği içeren çizimler $(n=22, \% 65)$ hem de kitap, notlar vb. gibi bilgi sembollerini içeren çizimler $(n=20, \% 59)$ yaptıkları görülmüştür. Dördüncü sınıf düzeyindeki öğrenciler $(n=21, \% 67)$ de bilim insanını en çok bilgi sembollerini kullanırken resmetmişlerdir. Cinsiyet açısından ABT sembollerine bakıldığında, kız öğretmen adaylarında hem araştırma sembollerinin ( $n=28, \% 54)$ hem de bilgi sembollerinin ( $\mathrm{n}=27, \% 52)$ ağırlıklı kullanıldığı; erkek öğretmen adaylarında ise ağırlıkla bilgi sembollerinin (n= 19, \%54) kullanıldığı görülmüştür. 


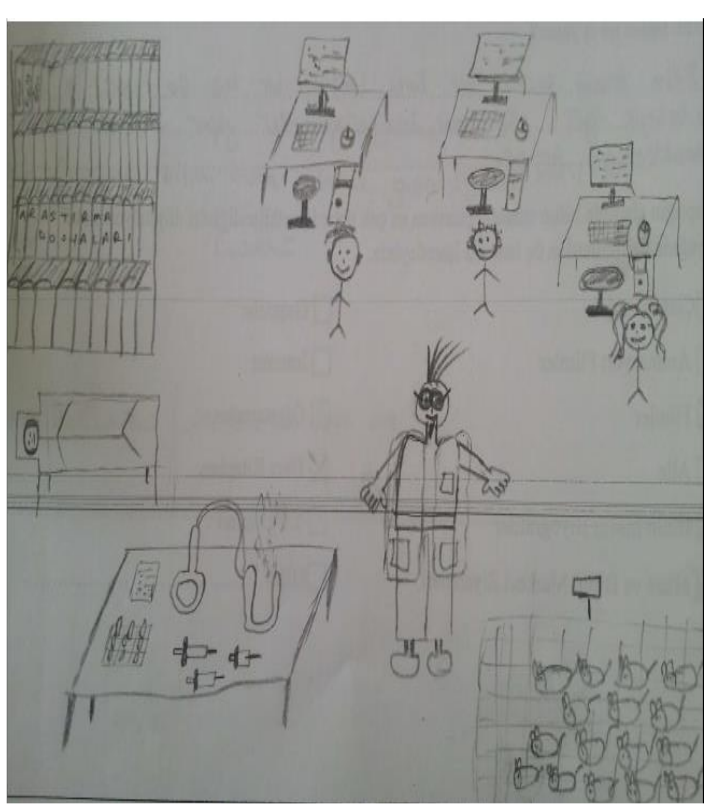

Şekil 3: Araştırma, teknoloji sembolleri içeren erkek bilim insanı çizimi; 1 . sınıf $\mathrm{k} 1 \mathrm{z}$

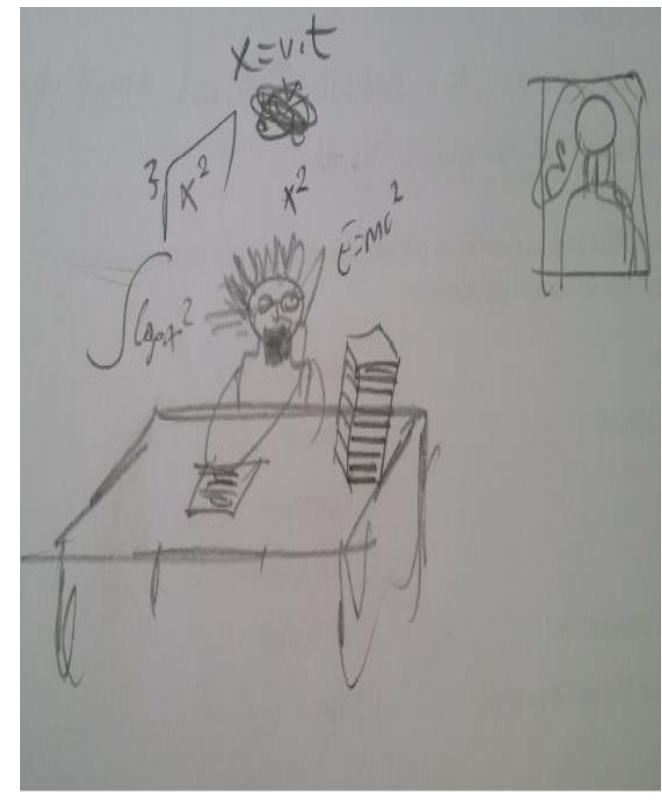

Şekil 4: Bilgi sembolleri içeren erkek bilim insanı çizimi; 4. sınıf erkek

\section{Bilim İnsanının Cinsiyeti, Çalıșma Ortamı ve Alternatif Semboller}

Tablo 4. Bilim insanının Cinsiyetine, Çalışma Ortamına ve Kullanılan Alternatif Semboller

\begin{tabular}{lllllll}
\hline \multirow{2}{*}{ N=87) } & \multicolumn{3}{c}{ Cinsiyet } & & \multicolumn{3}{c}{ Sınıf } \\
\cline { 6 - 7 } & Kız f(\%) & Erkek f(\%) & $\begin{array}{l}\text { Toplam } \\
\text { f(\%) }\end{array}$ & 1.Sınıf f(\%) & 3.Sınıf f(\%) & 4.Sınıf f(\%) \\
\hline Kadın & $12(23)$ & $3(9)$ & $15(17)$ & $4(12)$ & $2(10)$ & $9(28)$ \\
Erkek & $36(69)$ & $28(80)$ & $64(74)$ & $29(85)$ & $14(67)$ & $21(66)$ \\
Kad+ Erk & $3(6)$ & $4(11)$ & $7(8)$ & $1(3)$ & $4(19)$ & $2(6)$ \\
İç Mekân & $43(82)$ & $26(74)$ & $69(79)$ & $31(91)$ & $14(67)$ & $24(75)$ \\
Dış Mekân & $8(15)$ & $7(20)$ & $15(17)$ & $3(9)$ & $5(24)$ & $7(22)$ \\
Yalnız & $47(90)$ & $31(87)$ & $78(90)$ & $33(97)$ & $15(71)$ & $30(94)$ \\
Grup & $4(8)$ & $3(9)$ & $7(8)$ & $1(3)$ & $4(19)$ & $2(6)$ \\
BAS & $12(23)$ & $3(9)$ & $15(17)$ & $4(12)$ & $7(33)$ & $4(13)$ \\
Tehlike & $13(25)$ & $6(17)$ & $19(22)$ & $8(24)$ & $5(24)$ & $6(19)$ \\
Gülümseme & $22(42)$ & $4(11)$ & $26(30)$ & $11(32)$ & $6(27)$ & $9(28)$ \\
\hline
\end{tabular}

Tablo 4’e göre cinsiyet ya da sınıf ayrımı gözetilmeksizin öğretmen adaylarının \%74 (n=64)'ünün bilim insanını erkek, \%17 (n=15)'sinin ise bilim insanını kadın çizdiği ortaya çıkmıştır. Öğretmen adaylarının \%8 (n=7)’i ise hem kadın hem de erkek bilim insanı çizmişlerdir. Sınıf düzeylerine göre değerlendirildiğinde her sınıf düzeyinde erkek bilim insanı figürünün baskın olduğu görülmektedir. 
Cinsiyete göre öğretmen adaylarının bilim insanları çizimleri incelendiğinde ise, erkek öğretmen adaylarının \%80 (n=28)'i “erkek"; \%9 (n=3)’u "kadın” bilim insanı çizerken; kadın öğretmen adaylarının \%69 (n=36)'u “erkek"; \%23 (n=12)'ü ise "kadın” bilim insanı çizmişlerdir.

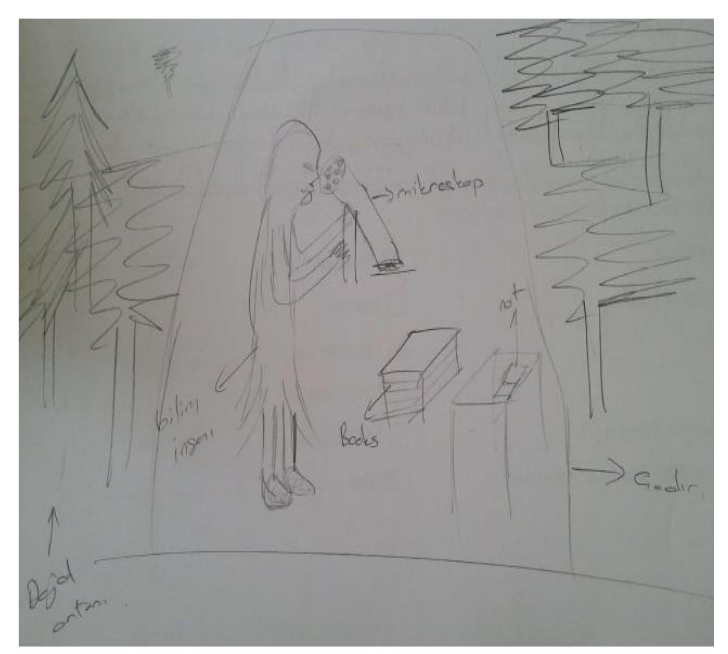

Şekil 5: Doğada, mikroskop ile araştırma yapan kadın bir bilim insanı; 4. sinif erkek

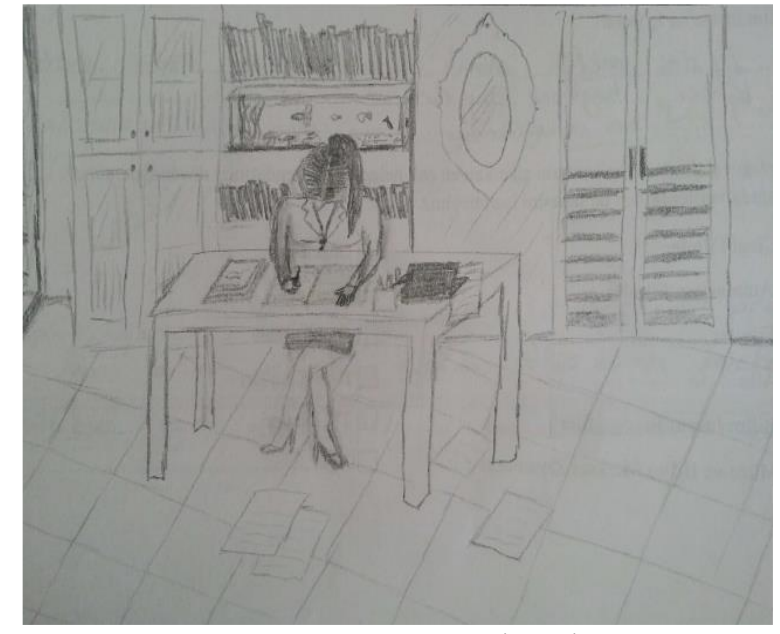

Şekil 6: Ofisinde not tutarak çalışan kadın bir bilim insanı; 1 sınıf kız

Öğretmen adaylarının çizimleri, bilim insanının çalışma mekânı ve yalnız ya da grupla çalışması açısından değerlendirildiğinde, sınıf düzeyi ya da cinsiyet gözetilmeksizin öğrencilerin birçoğunun bilim insanını iç mekânda (n=69, \%79) ve yalnız (n=78,\%90) çalışırken ifade ettiği görülmüştür.

Cinsiyet açısından bakıldığında, hem kız ( $\mathrm{n}=43, \% 82)$ hem de erkek $(\mathrm{n}=26, \% 74)$ öğrencilerin büyük bir çoğunluğu bilim insanını iç mekânda çalışırken resmetmiştir. Ve yine her iki cinsiyetteki öğretmen adaylarının tamamına yakını (Kız=\%090; Erkek=\%87) bilim insanını yalnız çalışan biri olarak çizmişlerdir. Sınıf düzeyleri açısından değerlendirildiğinde, her grupta da öğrenciler en çok iç mekânda (1. sınıf= $\% 91,3 . \sin 1 f=\% 67 ; 4 . \sin 1 f=\% 75)$, yalnız çalışan $(1 . \sin 1 f=\% 97 ; 3 . \sin 1 f=\% 71 ; 4$. sınıf $=\% 94)$ bilim insanları çizmişlerdir. 


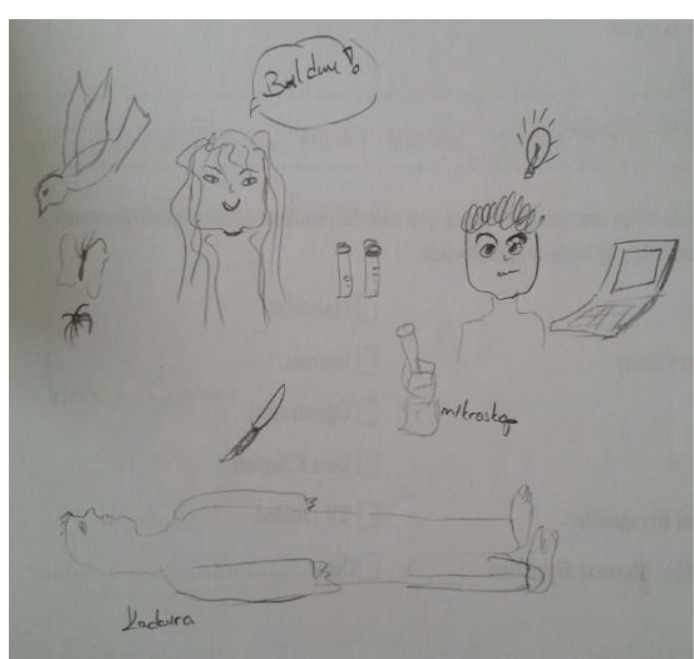

Şekil 7: İç mekânda, grup olarak çalışan bilim insanları; 3. sınıf kız

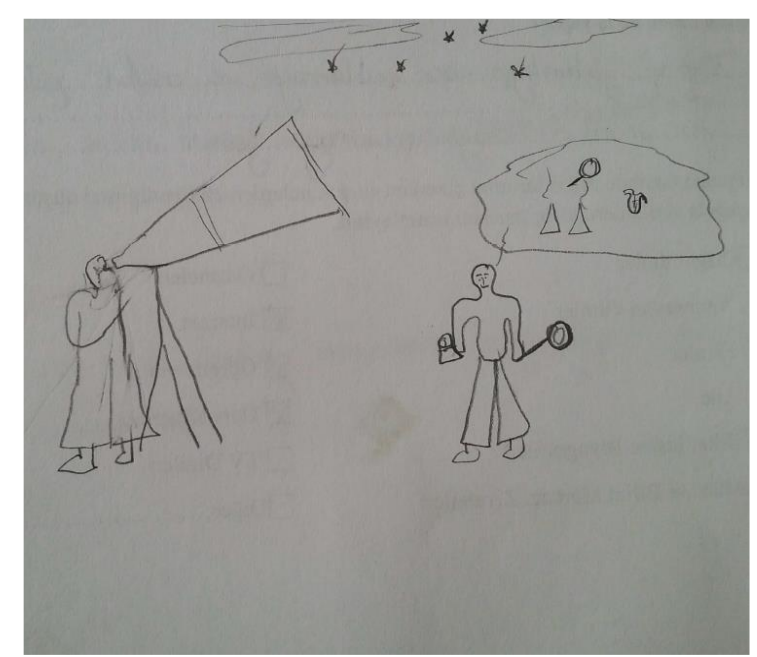

Şekil 8: Dış mekânda, grup olarak çalışan bilim insanları; 1. sınıf kız

Üstün zekâlılar öğretmenliği adaylarının başlık-altyazı-simge (BAS) ve alternatif imajlar kullanımı açısından özellikle kız öğretmen adaylarının çizimlerinde gülümseyen $(\mathrm{n}=22, \% 42)$ bilim insanları öne çıkan imajlardan olmuştur. 1. sınıf düzeyindeki öğretmen adaylarının gülümseme $(\mathrm{n}=11, \% 32)$ sembollerini daha çok kullandıkları görülürken, 3. sınıf öğretmen adaylarının çizimlerinde BAS'ları $(n=7, \% 33)$ ön plana çıkardıkları görülmüştür.

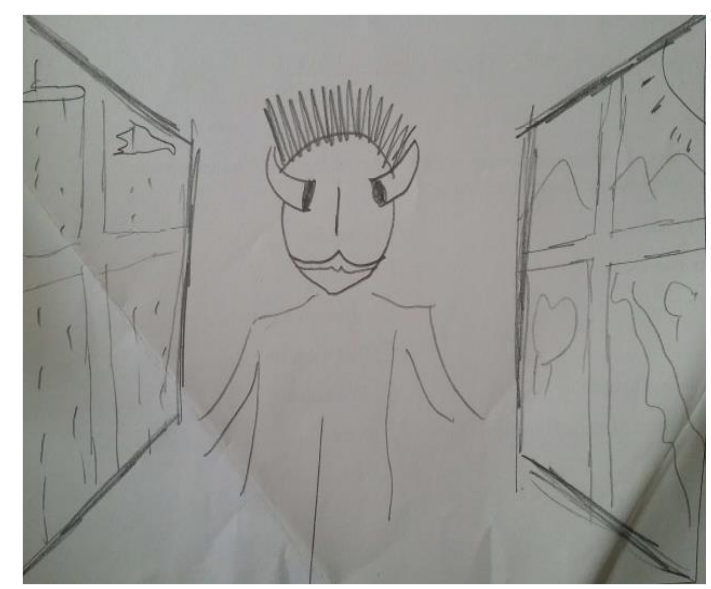

Şekil 9: Alternatif bilim insanı çizimi; 4. sinif erkek

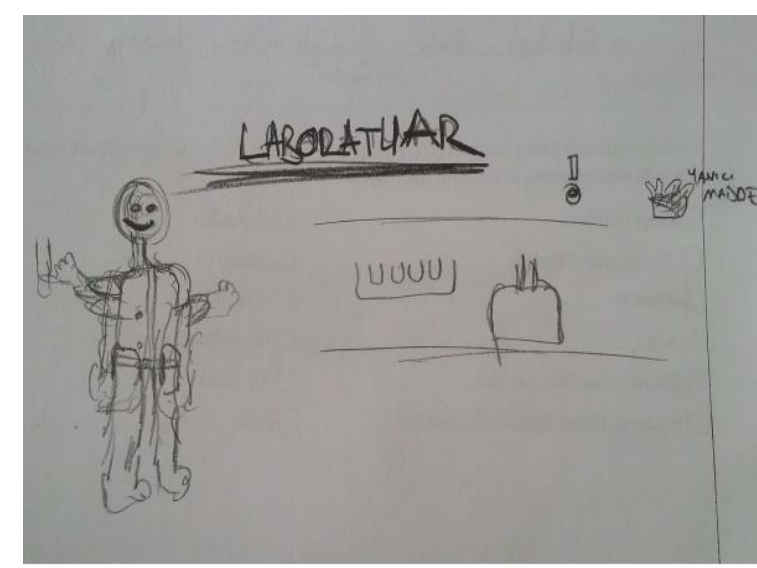

Şekil 10: Başlık ve sembol içeren bilim insanı çizimi; 1. sınıf kız 


\section{Bilim İnsanının Yaşı}

Tablo 5’te verilen bulgulara göre öğretmen adaylarının \%44'ünün (n=38) bilim insanını 30 ile 40 yaş arasında hayal ettiği görülmüştür. Cinsiyet açısından bakıldığında ise, hem erkek öğretmen adayları $(n=19, \% 54)$ hem de kız öğretmen adayları $(n=19$, \%37) 30-40 yaş arasında bilim insanları çizmişlerdir.

1. sınıf düzeyindeki öğretmen adayları bilim insanını daha çok 40-50 yaşları arasında çizimlerken $(n=11, \% 32), 3$. sinıf $(n=10, \% 48)$ ve 4. sinıf $(n=20, \% 63)$ ögrretmen adayları ise bilim insanını daha çok 30-40 yaş arasında çizimlemişlerdir.

Tablo 5. Bilim Insanının Yaşına Yönelik Imajların Frekans ve Yüzdesi

\begin{tabular}{lllllll}
\hline \multirow{2}{*}{ N=87) } & \multicolumn{2}{c}{ Cinsiyet } & & \multicolumn{3}{c}{ Sinıf } \\
\cline { 2 - 4 } \cline { 5 - 6 } & \multirow{5}{*}{ Kız f(\%) } & Erkek f(\%) & Toplam f(\%) & 1.Sinıf f(\%) & 3.Sinıf f(\%) & 4.Sinıf f(\%) \\
\hline $10-20$ & $3(6)$ & $0(0)$ & $3(3)$ & $2(6)$ & $0(0)$ & $1(3)$ \\
$20-30$ & $12(23)$ & $2(6)$ & $14(16)$ & $7(21)$ & $2(10)$ & $5(16)$ \\
$30-40$ & $19(37)$ & $19(54)$ & $38(44)$ & $8(24)$ & $10(48)$ & $20(63)$ \\
$40-50$ & $9(17)$ & $10(29)$ & $19(22)$ & $11(32)$ & $4(19)$ & $4(13)$ \\
$50-60$ & $7(14)$ & $3(9)$ & $10(11)$ & $4(12)$ & $4(19)$ & $2(7)$ \\
$60-$ & $2(4)$ & $1(3)$ & $3(3)$ & $2(6)$ & $1(5)$ & $0(0)$ \\
\hline
\end{tabular}

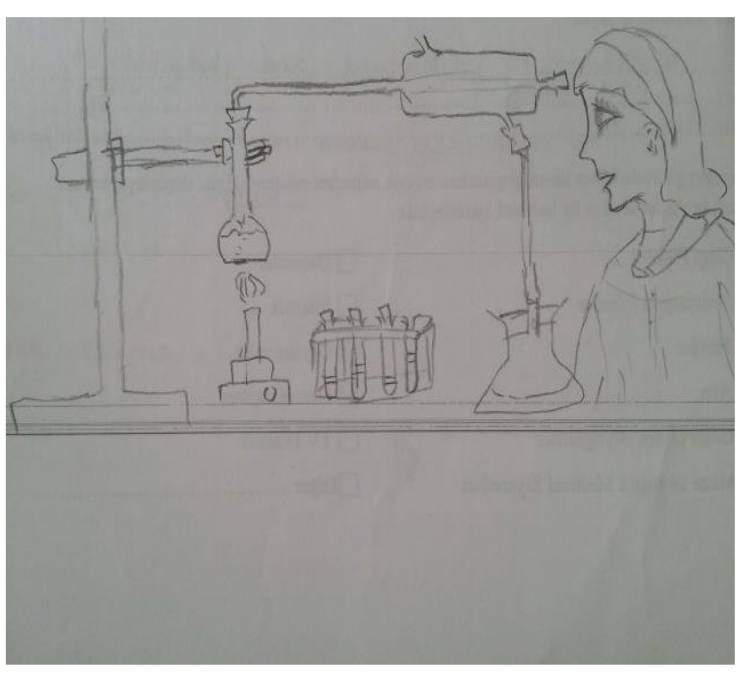

Şekil 11: Yaş1 10-20 arası olan bilim insanı çizimi; 1. sınıf kız

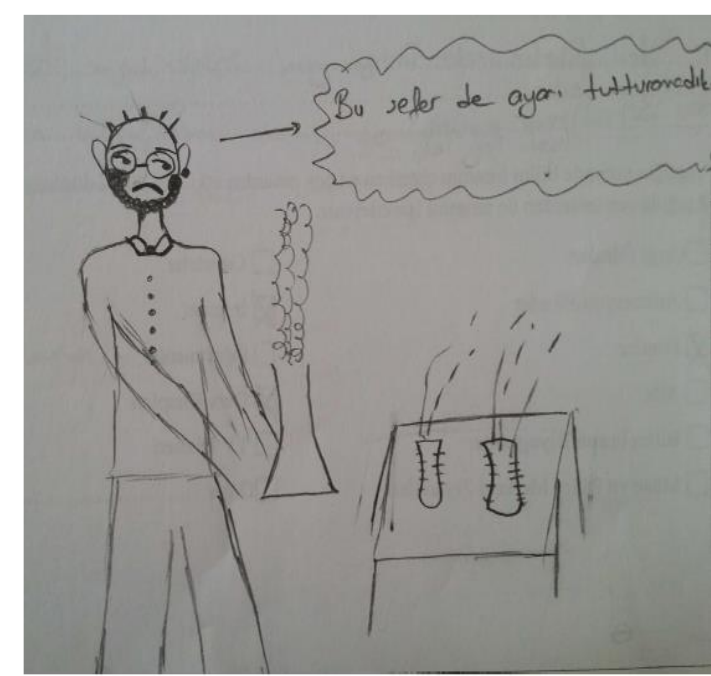

Şekil 12: Yaş1 40-50 arası olan bilim insanı çizimi; 3. sınıf kız 


\section{"Favori bilim insanın/insanların (Einstein, Marie Curie, Edison, Robert}

\section{Boyle, vb.) kimdir?"}

Üstün zekâlılar öğretmen adaylarının "Favori bilim insanın/insanların (Einstein, Marie Curie, Edison, Robert Boyle, vb.) kimdir?” sorusuna vermiş oldukları cevaplar incelendiğinde hem k1z ( $\mathrm{n}=16, \% 31)$ hem de erkek (12, \%34) öğretmen adaylarının en favori bilim insanının "Einstein" olduğu; Edison'un da ikinci sırada yer aldığı görülmüştür (n toplam=15, \%14). Sınıf düzeyleri açısından değerlendirildiğinde ise her sınıf düzeyinde favori gösterilen bilim insanının Einstein olduğu görülmüştür.

Tablo 6. "Favori bilim insanın/insanların (Einstein, Marie Curie, Edison, Robert Boyle, vb.) kimdir?"

\begin{tabular}{|c|c|c|c|c|c|c|}
\hline \multirow[t]{2}{*}{$(\mathrm{N}=87)$} & \multicolumn{2}{|c|}{ Cinsiyet } & \multirow[b]{2}{*}{ Toplam f(\%) } & \multicolumn{3}{|l|}{ Sinıf } \\
\hline & Kuz f $(\%)$ & Erkek f(\%) & & 1.Sinif f(\%) & 3.Sinıf f(\%) & 4.Sinif $f(\%)$ \\
\hline Einstein & $16(31)$ & $12(34)$ & $28(32)$ & $9(27)$ & $6(29)$ & $13(41)$ \\
\hline Edison & $11(21)$ & $4(11)$ & $15(14)$ & $8(24)$ & $2(10)$ & $5(16)$ \\
\hline Graham Bell & $3(6)$ & $1(3)$ & $4(5)$ & $2(6)$ & $1(5)$ & $1(3)$ \\
\hline Tesla & 1(2) & $4(11)$ & $5(6)$ & 1(3) & $2(10)$ & $2(6)$ \\
\hline Marie Curie & $3(6)$ & $1(3)$ & $4(5)$ & $2(6)$ & $0(0)$ & $2(6)$ \\
\hline Hepsi & $0(0)$ & 1(3) & 1(1) & $2(6)$ & $0(0)$ & $0(0)$ \\
\hline Fikrim Yok & $1(2)$ & $0(0)$ & $1(1)$ & 1(3) & $0(0)$ & $0(0)$ \\
\hline Yanit Yok & $8(15)$ & $7(20)$ & $15(14)$ & $2(6)$ & $8(38)$ & $5(16)$ \\
\hline
\end{tabular}

$\mathrm{Bu}$ noktada toplam öğrencilerin \%14'ünün $(\mathrm{n}=15)$ yanıtı olmaması da ortaya çıkan bulgular arasındadır. Bu konuda, üstün zekâlılar öğretmenliği adaylarından favori bilim insanlarının kim olduğunu nedenleri ile yazmaları talep edilmiştir. Aşağıda öğretmen adaylarının neden olarak gösterdiği ifadelere yer verilmektedir:

“...Einstein. Hakkında ne kadar araştırma yapmasam da zekâsı apaçık ortada. Hayran olmamak elde değil..."

“...Einstein, ilginç bir hayat hikâyesi olduğu, onu önce aptal sandıkları için..."

“...Edison, dünyayı aydınlattığı, yılmadan çalıştığı için saygı duyuyorum...” 
“...İbn-i Sina. Yaptı̆̆ı çalışmalar hem döneminin kısıtlı imkanları ile ve sabırla yapılmış hem de günümüzde hala kullanılmakta..."

“Etrafınızda bilim insanı olarak gördüğünüz insan/insanlar var mı? Var ise

\section{bunlar kimlerdir?"}

Tablo 7. "Etrafinızda bilim insanı olarak gördügünüz insan/insanlar var mı? Var ise bunlar kimlerdir?"

\begin{tabular}{|c|c|c|c|c|c|c|}
\hline \multirow[t]{2}{*}{$(\mathrm{N}=87)$} & \multicolumn{2}{|l|}{ Cinsiyet } & \multirow[b]{2}{*}{ Toplam f(\%) } & \multicolumn{3}{|c|}{ Sinıf } \\
\hline & Kuz f(\%) & Erkek f(\%) & & 1.Sinıf f(\%) & 3.Sinıf f(\%) & 4.Sinıf $\mathrm{f}(\%)$ \\
\hline Akademisyen & $5(10)$ & $3(9)$ & $6(7)$ & $2(6)$ & $0(0)$ & $6(19)$ \\
\hline Öğretmenler & $1(2)$ & $0(0)$ & 1(1) & 1(3) & $0(0)$ & $0(0)$ \\
\hline Arkadaş & 2(4) & 1(3) & $3(3)$ & $2(6)$ & $0(0)$ & 1(3) \\
\hline Akraba & 2(4) & $2(6)$ & $4(5)$ & $2(6)$ & $0(0)$ & $2(6)$ \\
\hline Yok & $42(81)$ & $25(71)$ & $67(77)$ & $26(77)$ & $20(95)$ & $21(66)$ \\
\hline
\end{tabular}

Tablo 7'de yer alan üstün zekâlılar öğretmenliği adaylarının "Etrafınızda bilim insanı olarak gördüğünüz insan/insanlar var mı? Var ise bunlar kimlerdir?” sorusuna vermiş oldukları cevaplar incelendiğinde sınıf ya da cinsiyet gözetmeksizin öğretmen adaylarının büyük çoğunluğunun $(n=67, \% 77)$ etraflarında bilim insanı olarak gördüğü insanlar olmadığını ifade ettikleri görülmüştür. Etraflarında bilim insanı olarak gördükleri biri olduğunu ifade edenler ise en çok “akademisyenleri” bilim insanı olarak gördüklerini söylemişlerdir. Cevapları ile ilgili sundukları nedenlerin bazıları ise:

“...yok, olsaydı ben de biraz bu konulara ilgili olabilirdim belki. Ve bu ailenin eğitim seviyesine bağlı bir şey bence..."

“...yok, çünkü herkes sıradan...”

“...yok. Olaylara eleştirel gözle bakan insan çok az. Olayların arkasındaki nedenleri irdeleyen, sabırla ve azimle araştırma yapan insan yok..."

“...var, dayım. Sürekli bir şeyler üretmeye çalışır. Merak eder, gözlemcidir.

Araştırır, çalışmayı çok sever...” gibidir. 


\section{Tartışma ve Sonuç}

Üstün zekâlılar öğretmenliği adaylarının gözlerinden bilim insanlarını nasıl gördüklerini ortaya koymayı amaçlayan bu çalışmanın sonucunda, öğretmen adaylarının her iki cinsiyette ve her sınıf düzeyinde bilim insanını fiziksel görünüş açısından en çok “gözlük”, “önlük” ve “dağınık görüntü” ile hayal ettiği ortaya çıkmıştır. Bu daha önce ilköğretim ya da ortaöğretim öğrencileri ile yapılan çalışma sonuçları ile benzemekle birlikte (Akcay, 2011; Buldu, 2006; Camc1, 2008; Camc1-Erdoğan, 2013a, 2013b; Chambers, 1983; Flick, 1990; Fort ve Varney, 1989; Fung, 2002; Gonsoulin 2001; Kaya, Doğan ve Öcal, 2008; Kemaneci, 2012; Mead ve Metraux, 1957; Schibeci, 2006; Song ve Kim, 1999; Symington ve Spurling, 1990; Türkmen, 2008; Yontar-Toğrol, 2000) öğretmen adayları ile yapılan çalışmalara da paralellik göstermektedir (Çermik, 2013; Moseley ve Norris, 1999; Ünver, 2010). Mevcut çalışmada ve daha önceki çalışmalarda (Ünver, 2010; Yontar-Toğrol, 2000) yer alan öğrenci görüşlerinden yola çıkarak, çizimlerde yoğunluklu olarak gözlük ve dağınık görünümün ön plana çıkmış olmasının bilim yapmanın yorucu bir iş olduğu düşüncesinden kaynaklandığı söylenebilir. Bununla birlikte bu tarz figürlerin medya organlarında ve ders kitaplarında en çok kullanılan figürler olduğu göz önünde bulundurulmalıdır.

Konu ile ilgili daha önce yapılan çalışmalarda da özellikle görsel medya ve ders kitaplarının kalıp bilim insanı imajlarının oluşmasında ciddi bir etken olduğu ortaya koyulmuştur (Camc1-Erdoğan, 2013a, 2013b; Schibeci, 1986; Song ve Kim, 1999; Yontar-Toğrol, 2000). Bu noktada görsel ve yazılı medyanın ve ders kitaplarının bilim insanlarının dış görünüş özelliklerine dair imajlara etkisi olduğunu söylemek yanlış olmaz. 
Çizimlerde bilim insanının kullandığı sembollere ve çalıştığı mekâna yönelik sonuçlara bakıldığında, öğretmen adaylarının çoğunlukla "beher, tüp içerisinde kimyasallar" gibi araştırma sembolleri ile "kitap, defter, not” gibi bilgi sembollerini kullanarak laboratuvarda (iç mekânda) yalnız çalışan bilim insanları çizdikleri görülmüştür. Sınıf düzeyi açısından bakıldığında birinci sınıflarda hem araştırma hem de bilgi sembolleri ağırlıkla görülürken, üst sınıf düzeylerine çıkıldıkça bilgi sembollerinde artış görülmüştür. Tüm sınıf düzeylerinde bilim insanları baskın bir şekilde iç mekânda (laboratuvarda) yalnız çalışırken çizilmiştir. Öğretmen adaylarının çoğunluğu çizimlerinde de, açık uçlu sorularda da laboratuvarda farklı karışımları çizerek ya da sözel olarak vurgulayarak bilim insanlarının araştırma yaptıklarını ifade etmişlerdir. $\mathrm{Bu}$ yüzden, öğretmen adaylarının bilim insanlarının çoğunlukla laboratuvarda çalıştığını ve burada deney yaptığını yansıtmak amacı ile araştırma sembolleri kullanmış olabileceği düşünülebilir. Daha önce yapılan çalışmalarda (Çermik, 2013; Reap, Cavallo ve McWhirter, 1994; Ünver, 2010; Yetim, 1996) da görülen bu sonucun öğretmen adaylarının sahip olduğu imajlar üzerinde; TV, sinema, gazete vb. medya araçlarında özellikle bilim insanlarının laboratuvar ortamında "deney tüpleri, kimyasallar vb. laboratuvar araç ve gereçleri” ile toplumdan tecrit olmuş, uzak bir mekânda yalnız çalışırken resmedilmesinden kaynaklandığı söylenebilir. Bu durum üzerinde daha önceki çalışmalarda da (Camc1-Erdoğan, 2013a, 2013b; Schibeci, 1986; Song ve Kim, 1999; Türkmen, 2008; Yontar-Toğrol, 2000) ifade edildiği gibi özellikle görsel medyanın oldukça etkili olduğu söylenebilir. Zira birçok görsel medya unsurunda bilim insanı halktan uzakta, gizemli alanlarda çalışırken yansıtılmaktadır. Sınıf düzeyi arttıkça bilgi sembollerinin artmasında ise, sınıf düzeyi arttıkça farklı ders içeriklerinde literatür araştırma ödevlerinin verilmesi ve bunun sonucunda bilginin farklı 
kaynaklardan araştırılarak teorik olarak da üretilebileceğinin fark edilmiş olması olabilir.

Üstün zekâlılar öğretmenliği adayları cinsiyet ve sınıf düzeyi fark etmeksizin büyük çoğunlukla "erkek” bilim insanı çizmişlerdir. Cinsiyet, yaş ve sınıf düzeyi ne olursa olsun bilim insanı çizimlerinde çoğunlukla erkek bilim insanı çiziliyor olması birçok (Buldu, 2006; Camc1-Erdoğan, 2013a, 2013b; Chambers, 1983; Çermik, 2013; Flick, Fort ve Varney, 1989; Fung, 2002; Gonsoulin, 2001; Kaya, Doğan ve Öcal, 2008; Kemaneci, 2012; Mead ve Metraux, 1957; Narayan et. al., 2007; Schibeci, 2006; Song ve Kim, 1999; Symington ve Spurling, 1990; Türkmen, 2008; Ünver, 2010; YontarToğrol, 2000) sonuçlara paralellik göstermekle birlikte, mevcut araştırmada kız öğretmen adayları ile birlikte erkek öğretmen adaylarının da kadın bilim insanı çizdiği görülmüştür. $\mathrm{Bu}$ durumun kadınların fen bilimlerinde temsiliyet düzeyinin düşük olmasının çözümlenmesinde umut vaat edici bir gelişme olduğu söylenebilir. Zira fen bilimlerinin erkeğe özgü olduğu düşüncesi ilkokul seviyesinden lisans seviyesine kadar olan tüm bireylerde görülmekte ve bu toplam tarafindan da onanmaktadır. Mevcut çalışma çerçevesinde bu algının kısmen devam ettiğini ve hem kız öğretmen adayları hem de erkek öğretmen adaylarının kadın bilim insanı çizmelerinin umut vaat eden bir durum olduğunu söylemek yanlış olmaz.

Özellikle fen bilimlerinde sadece erkeklerin var olduğunun düşünülmesi, bilimde kadınların varlığının az olması ya da az yansıtılması kız öğrencilerin fen bilimlerine yönelik alanlarda ilgilerini geliştirmesini ya da bu alanda meslek seçmesini olumsuz etkilemektedir. Eğitim öğretimin her düzeyinde (okul öncesinden-lisansüstüne kadar) erkekler kadar, kız öğrencilerin de fen bilimlerine yönelik alanlarda desteklenmesi için 
öğretmenlerin, mentörlerin, ailelerin ve toplumun diğer kesimlerinin (işveren vb.) bu duruşa destek vermesi ve onaylaması beklenmektedir.

Öğretmen adaylarının çizdikleri imajlara yaş açısından bakıldığında, adayların kendi yaş düzeylerine yakın yaş aralıklarını seçmediği, genel olarak otuz-kırk yaş aralığını seçtiği ortaya çıkmıştır. Bilimin genel olarak orta yaş diyebileceğimiz yaş aralığında olan insanlar tarafından yapılabileceği düşüncesinin, görsel medya ve ders kitaplarında yer alan orta yaş imajlarından etkilenilerek ortaya çıktığı düşünülebilir. Bu noktada öğretmen adayları, her yaştan insanın bilimsel yöntemi kullanarak bilim yapabileceği mesajını verebilecek etkinliklere ve proje çalışmalarına katılmaları ve ürünler ortaya koymaları açısından desteklenmelidir.

Öğretmen adayları favori bilim insanı olarak ise en çok Einstein ve daha sonra da Edison'u, ifade etmişlerdir. Bu bulgu Çermik (2013), Rubin, Bar ve Cohen (2003) ve Ünver (2010)'in çalışmalarına paralellik göstermiştir. Bununla birlikte bilime katk1 sağlayan Türk bilim insanlarının ve özellikle kadın bilim insanlarının çok fazla belirtilmemesi ise dikkat çekmektedir. Öğrencilerin vermiş olduğu cevapların sebeplerine bakıldığında, genel olarak favori gösterilen bilim insanının yaşamına, kişisel özelliklerine ve insanlığa sağladıkları katkıya vurgu yapıldığı görülmektedir. Yine adayların büyük bir çoğunluğu etraflarında bilim insanı olarak tanımlayabilecekleri hiç kimse olmadığını; sebebini ise bilim insanına yönelik oluşturdukları özelliklere kimsenin sahip olmaması, kimsenin araştırma/deney yapmaması ve topluma faydalı yeni şeyler üretmemesi olduğunu ifade etmişlerdir. $\mathrm{Bu}$ sebeple öğrencilerin bilim, bilimsel yöntem, bilimin doğası ve bilim insanları gibi konularda daha derinlemesine bilgilendirilmeleri gerektiği ve her yaş ve düzeyde bilim yapılabileceğinin mesajının verilmesi gerektiği söylenebilir. 
Günümüze kadar yapılmış birçok çalışma öğretmenlerin bilime/ bilim insanına yönelik sahip oldukları tutumların, ilgi ve imajların öğrencilerin de sahip olduğu tutum, ilgi ve imajları etkilendiğini ortaya koymuştur (Altınok, 2004; Morell ve Lederman, 1998; Palmer, 2001). Bu yüzden özellikle, bilime yönelik içten derin ilgi ve merak duyan üstün zekâlı öğrencilere eğitim veren öğretmenlerin de bilime yönelik olumlu tutum geliştirmeleri, öğrencilerinin de bilime yönelik olumlu tutum geliştirebilmesi ve bilimden zevk alabilmesi için önemlidir. $\mathrm{Bu}$ yüzden üstün zekâlılar öğretmenli adaylarının sahip olduğu bilim insanlarına yönelik imajlarının basmakalıp fikirlerden uzak olması ve açık olması önemlidir. Bu bağlamda öğretmen adaylarının lisans öğretimi süresince alacakları lisans derslerinin bilimin her tülü dalı ile ilişkilendirilmesi, bilimin ve bilimsel yöntemin nasıl yapılacağına ve günlük hayata entegre edileceğine dair fikirler vermesi önemlidir. Öğretmen adaylarının sahip olduğu bilim insanı imajı ile karşı karşıya kalmaları, bu imajları eleştirmeleri ve yeniden yapılandırmaları sağlanmalıdır. Öğretmen adaylarının bilimsel düşünceyi ve yöntemi hayatlarının bir parçası haline getirmeleri ve uygulamaları için yönlendirmeler ve firsatlar sağlanmalıdır. Proje çalışmaları ve araştırma projeleri ile bilim yapmayı deneyimlemeleri sağlanmalıdır. Günümüz bilim insanlarının çalışmalarından örnekler verilmeli, hatta üniversitelerde bu bilim insanları ile çalışmaları sağlanmalı ve bilimin çok uzakta aranmaması gerektiği vurgulanmalıdır.

\section{Sinırlılıklar}

Çalışmada, üstün zekâlılar öğretmen adaylarının favori bilim insanlarının belirlenmesinde kullanılan açık uçlu soruda, parantez içinde kullanılan örneklerin, sorunun cevabında yönlendirici olması açısından çalışmanın bir sınırlılığı olduğu söylenebilir. 


\section{Öneriler}

Mevcut çalışmaya, üstün zekâlılar öğretmenliği programında öğrenim gören 87 öğretmen adayı katılmıştır. Bu bağlamda tüm üstün zekâlılar öğretmenliği adaylarına genellenemez ama durum hakkında fikir vermektedir. Benzer çalışmaların farklı düzey ya da meslek grupları ile farklı desenlerde yürütülmesi önerilebilir.

\section{Makalenin Bilimdeki Konumu (Yeri)}

Özel Eğitim Bölümü/ Üstün Zekâlılar Eğitimi Anabilim Dalı-Özel Yetenekliler Eğitimi Anabilim Dalı

\section{Makalenin Bilimdeki Özgünlüğü}

Bilginin üretilmesinin ve yeni bilgi ve teknolojilerinin ortaya koyulmasının her ülke açısından birincil derecede önemli olduğu günümüzde, üstün zekâlı öğrenciler bu yeni bilgi ve teknolojileri üretme potansiyeline sahip öğrenciler olarak görülmektedir. $\mathrm{Bu}$ öğrencilerin var olan potansiyellerini daha da iyiye götürme, bilimsel bilgiyi kullanma ve yenilerini üretme açısından onlara eğitim verecek öğretmenlerin sahip olduğu özellikler çok önemlidir. Bilim ve bilim insanlarına yönelik oluşturulacak yanlış alg1 ve imajlar üstün zekâlı öğrencilerin bilime ve bilim insanına bakış açısını da olumsuz etkileyecektir. Bu yüzden üstün zekâlılara eğitim verecek öğretmen adaylarının sahip olduğu bilim insanı imajlarının ortaya koyulması, bu öğrencilerin daha doğru yönlendirilebilmesi açısından önemlidir.

\section{Teşekkür}

Mevcut çalışmaya, 54180 kodlu proje kapsamında destek veren İstanbul Üniversitesi Bilimsel Araştırma Projeleri Koordinasyon birimine teşekkürlerimi sunarım. 


\section{Kaynakça}

Akçay, B. (2011). Turkish elementary and secondary students' views about science and scientist. Asia-Pacific Forum on Science Learning and Teaching, 12(1), 1-11.

Altınok, H. (2004). Öğretmenlerin fen öğretimine yönelik tutumlarına ilişkin öğrenci algıları ve öğrencilerin fen bilgisi dersine yönelik tutum ve güdüleri. Hacettepe Üniversitesi Eğitim Fakültesi Dergisi, 26, 1-8.

Buldu, M. (2006). Young children's perceptions of scientists: A preliminary study. Educational Research. 48(1), 121-132. doi: 10.1080/00131880500498602

Camcı, S. (2008). Bilim şenliğine katılan ve katılmayan çocukların bilim ve bilim insanlarına yönelik ilgi ve imajlarının Karşılaştırılması (Yayımlanmamış yüksek lisans tezi). Hacettepe Üniversitesi, Ankara.

Camc1-Erdoğan, S. (2013a). Üstün zekâlı kızların bilime yönelik tutumları ve bilim insanı imajları. Hasan Ali Yücel Eğitim Fakültesi Dergisi, 10, 125-142.

Camc1-Erdoğan, S. (2013b). Üstün zekâlı ve yetenekli öğrencilerin bilim insanlarına yönelik algıları. Türk Üstün Zekâ ve Ĕgitim Dergisi, 3, 13-37.

Carnes, G. N. (2009). Interpreting drawings of preservice teachers. In J. E. Pederson \& K. D. Finson (Eds.), Visual data: Understanding and applying visual data to research in education (pp. 79-92). Rotterdam, The Netherlands: Sense.

Çermik, H. (2013). Öğretmen adaylarının zihinlerinde canlanan resimdeki bilim insanı. Pamukkale University Journal of Education, 33(1), 139-153. doi: 10.9779/PUJE612

Chambers, D. W. (1983). Stereotypic images of the scientist: The draw a scientist test. Science Education, 67(2), 255-265. doi: 10.1002/sce.3730670213

Christidou, V. (2011). Interest, attitudes and images related to science: Combining students' voices with the voices of school science, teachers, and popular science. International Journal of Environmental and Science Education, 6(2), 141-159.

Cooper, C. R., Baum, S. M., \& Neu, T. W. (2004). Developing scientific talent in students with special needs. Journal of Secondary Gifted Education, 15(4), 162169. 
Cooper, C. R., Baum, S. M., \& Neu, T. W. (2005). In Developing scientific talent in students with special needs. S. K. Johnsen \& J. Kendrick (Eds.), Science education for gifted students (pp. 63-78). Texas: Prufrock Press.

Demirbaş, M. (2009). Türkiye'deki bilim ve sanat merkezlerinde öğrenim gören üstün yetenekli öğrencilerin bilim adamı imgeleri. Journal of Qafqaz University, 28, 197-27.

Flick, L. (1990). Scientist in residence program improving children's image of science and scientists. School Science and Mathematics, 90(3), 204-214. doi: 10.1111/j.1949-8594.1990.tb15536.x

Fort, D.C., \& Varney, H.L. (1989). How students see scientists: Mostly male, mostly white, and mostly benevolent. Science and Children, 26(8), 8-13.

Fung, Y. Y. H. (2002). A comparative study of primary and secondary school students' 1mages of scientsts. Research in Science \& Technological Education, 20(2), 199213. doi: 10.1080/0263514022000030453

Gonsoulin, W. B. (2001). How do middle school students depict science and scientist?Unpublished doctoral dissertation, Mississippi State University, Mississippi.

Hammrich, P. L. (1997). Confronting the gender gap in science and mathematics: The Sisters in Science program. (Report No. SE059829). Oak Brook, IL: National Association for Research in Science Teaching. (ERIC Document Reproduction Service No. ED 406 167).

Karnes, F. A., \& Riley, T. L. (2005). Developing an early passion for science through competitions. S. K. Johnsen ve J. Kendrick (Ed.), Science education for gifted students içinde (s. 25-31). Texas: Prufrock Press.

Kaya, N. O, Doğan, A ve Öcal, E. (2008). Turkish elementary school students' images of scientists. Eurasian Journal of Educational Research, 32, 83-100.

Kemaneci, G. (2012). Üstün yetenekli öğrencilerin bilim insanı hakkındaki imajlarının araştırılması (Yayımlanmamış yüksek lisans tezi). Gazi Üniversitesi, Ankara.

Kopelman, M., Galasso, V. G., \& Strom, P. (1977). A model program for the development of creativity in science. Gifted Child Quarterly, 21(1), 80-84. 
Matthews, B., Davies, D. (1999). Changing children's images of scientists: Can teachers make a difference? School Science Review, 80(293), 79-85.

Mead, M., \& Metraux, R. (1957). Image of the scientist among high-school students. Science, 126 (3270), 384- 390. doi: 10.1126/science.126.3270.384

Meador, K. S. (2003). Thinking creatively about science: Suggestions for primary teachers. Gifted Child Today, 26(1), 25-29.

Milford, T. M., \& Tippett, C. D. (2013). Preservice teachers' images of scientists: Do prior science experiences make a difference?. Journal of Science Teacher Education, 24, 745-762. doi: 10.1007/s10972-012-9304-1

Milles, M.B., \& Huberman, A.M. (2002). The Qualitative Researcher's Companion. California: Sage Publications.

Morell, P. D., \& Lederman N.G. (1998). Students attitudes towards school and classroom science. School Science and Mathematics, 98(2), 76-83. doi: 10.1111/j.1949-8594.1998.tb17396.x

Moseley, C., \& Norris, D. (1999). Preservice teachers' views of scientists. Science and Children, 37(6), 50-53.

Ngoi, M., \& Vondracek, M. (2004). Working with gifted science students in a public high school environment. Journal of Secondary Gifted Education, 15(4), 141-147.

Palmer, D. H. (2001). Factors contrubuting to attitude exchange amongs preservice elementary teachers. Science Education, 86, 122-138. doi: 10.1002/sce.10007

Reap, M.A., Cavallo, A.M.L., \& McWhirter, L.J. (1994, January). Changing perceptions of scientists among preservice elementary school teachers. Paper presented at the annual international conference of the Association for the Education of Teachers in Science. El Paso, TX.

Rubin, E., Bar, V., \& Cohen, A. (2003). The images of scientists and science among Hebrew and Arabic-speaking pre-service teachers in Israel, International Journal of Science Education, 25(7), 821-846. doi: 10.1080/09500690305028

Schibeci, R. (2006). Student images of scientists: What are they? Do they matter?. Teaching Science, 52(2), 12-16. 
She, C. H., \& Fisher, D. (2002). Teacher communication behavior and its association with students' cognitive and attitudinal outcomes in science in Taiwan. Journal of Research in Science Teaching, 39(1), 63-78. doi: 10.1002/tea.10009

Smutny, J., \& Von Fremd, S. E. (2004). Differentiating for the young child. Thousand Oaks: Corwin Press.

Song J., \& Kim K. (1999) How Korean students see scientists: The images of the scientist. International Journal of Science Education, 21(9), 957-977. doi:10.1080/095006999290255

Sönmez, S. (2007). Preschool teachers' attitudes toward science and science teaching. Unpublished doctoral dissertation, Middle East Technical University, Ankara.

Symington, D., \& Spurling, H. (1990). The 'Draw a Scientist Test': Interpreting the data. Research in Science \& Technological Education, 8(1), 75-77. doi: $10.1080 / 0263514900080107$

Şenel, T. ve Aslan, O. (2014). Okulöncesi öğretmen adaylarının bilim ve bilim insanı kavramlarına ilişkin metaforik algıları. Mersin Üniversitesi Eğitim Fakültesi Dergisi, 10(2), 76-95.

Taber, K. S. (2007). Science education for gifted learners?. In K. S. Taber (Eds.), Science education for gifted learners (pp. 1-14). New York: Routledge.

Tassel-Baska, J.V., \& Kulieke, M.J. (1987). The role of community-based scientific resources in developing scientific talent: A case study. Gifted Child Quarterly, 3, 111-115.

Türkmen, H. (2008). Turkish primary students' perceptions about scientist and what factors affecting the image of scientists. Eurasia Journal of Mathematics, Science \&Technology Education, 4(1), 55-61.

Ünver, A. O. (2010). Perceptions of scientists: A comparative study of fifth graders and fourth year student teachers. Necatibey Faculty of Education Electronic Journal of Science and Mathematics Education, 4(1), 11-28.

Ürey, M., Karaçöp, A., Göksu, V. ve Çolak , K. (2017). Fen ve sosyal bilimler kökenli öğretmen adaylarının bilim insanı algıları. YŸ̈ Ĕ̆itim Fakültesi Dergisi, 14(1), 205-226. doi: 10.23891/yyuni.2017.8 
YYÜ Eğitim Fakültesi Dergisi (YYU Journal of Education Faculty), 2018; 15(1):130-155, http://efdergi.yyu.edu.tr

Washton, E. S. (1971). Improving elementary teacher education in science. New York: Macmillan.

Yetim, N. (1996). Farklı toplumsal kümelerde bilim ve bilim adamı imgesi (Yayımlanmamış Yüksek Lisans Tezi). Mersin Üniversitesi, Mersin.

Yontar-Toğrol, A. (2000). Öğrencilerin bilim insanı ile ilgili imgeleri. Eğitim ve Bilim, 25(118), 49-57. 